\title{
Selective Vulnerability of Striatal D2 versus D1 Dopamine Receptor-Expressing Medium Spiny Neurons in HIV-1 Tat Transgenic Male Mice
}

\author{
Christina J. Schier, ${ }^{1 \star}$ William D. Marks, ${ }^{1 *}$ ๑ Jason J. Paris, ${ }^{1}$ Aaron J. Barbour, ${ }^{2}$ Virginia D. McLane, ${ }^{1}$ \\ William F. Maragos, ${ }^{3,5}$ A. Rory McQuiston, ${ }^{2}$ Pamela E. Knapp, ${ }^{1,2,4}$ and $\odot$ Kurt F. Hauser ${ }^{1,2,4}$ \\ ${ }^{1}$ Department of Pharmacology and Toxicology, ${ }^{2}$ Department of Anatomy and Neurobiology, ${ }^{3}$ Department of Neurology, and ${ }^{4}$ Institute for Drug and Alcohol \\ Studies, Virginia Commonwealth University, Medical College of Virginia Campus, Richmond, Virginia 23298, and ${ }^{5}$ Neurology Service, Hunter Holmes \\ McGuire VA Medical Center, Richmond, Virginia 23224
}

Despite marked regional differences in HIV susceptibility within the CNS, there has been surprisingly little exploration into the differential vulnerability among neuron types and the circuits they underlie. The dorsal striatum is especially susceptible, harboring high viral loads and displaying marked neuropathology, with motor impairment a frequent manifestation of chronic infection. However, little is known about the response of individual striatal neuron types to HIV or how this disrupts function. Therefore, we investigated the morphological and electrophysiological effects of HIV-1 trans-activator of transcription (Tat) in dopamine subtype 1 (D1) and dopamine subtype 2 (D2) receptor-expressing striatal medium spiny neurons (MSNs) by breeding transgenic Tat-expressing mice to Drd1a-tdTomato- or Drd2-eGFPreporter mice. An additional goal was to examine neuronal vulnerability early during the degenerative process to gain insight into key events underlying the neuropathogenesis. In D2 MSNs, exposure to HIV-1 Tat reduced dendritic spine density significantly, increased dendritic damage (characterized by swellings/varicosities), and dysregulated neuronal excitability (decreased firing at $200-300 \mathrm{pA}$ and increased firing rates at $450 \mathrm{pA}$ ), whereas insignificant morphologic and electrophysiological consequences were observed in Tat-exposed D1 MSNs. These changes were concomitant with an increased anxiety-like behavioral profile (lower latencies to enter a dark chamber in a light- dark transition task, a greater frequency of light-dark transitions, and reduced rearing time in an open field), whereas locomotor behavior was unaffected by 2 weeks of Tat induction. Our findings suggest that D2 MSNs and a specific subset of neural circuits within the dorsal striatum are preferentially vulnerable to HIV-1.

Key words: basal ganglia; Drd1a-tdTomato-expressing neurons; Drd2-eGFP-expressing neurons; striatal indirect pathway; synaptic dysfunction; whole-cell patch-clamp physiology

\section{Significance Statement}

Despite combination antiretroviral therapy (cART), neurocognitive disorders afflict $30-50 \%$ of HIV-infected individuals and synaptodendritic injury remains evident in specific brain regions such as the dorsal striatum. A possible explanation for the sustained neuronal injury is that the neurotoxic HIV-1 regulatory protein trans-activator of transcription (Tat) continues to be expressed in virally suppressed patients on cART. Using inducible Tat-expressing transgenic mice, we found that dopamine subtype 2 (D2) receptor-expressing medium spiny neurons (MSNs) are selectively vulnerable to Tat exposure compared with D1 receptor-expressing MSNs. This includes Tat-induced reductions in D2 MSN dendritic spine density, increased dendritic damage, and disruptions in neuronal excitability, which coincide with elevated anxiety-like behavior. These data suggest that D2 MSNs and specific circuits within the basal ganglia are preferentially vulnerable to HIV-1.

\section{Introduction}

Despite the use of combination antiretroviral therapy (cART), neurocognitive disorders afflict $30-50 \%$ of HIV-infected indi- viduals. Although the precise mechanisms underlying the constellation of neurological deficits (including motor, mood,

J.J.P., A.J.B., V.D.M., W.F.M., A.R.M., and K.F.H. analyzed data; C.J.S., W.D.M., J.J.P., W.F.M., A.R.M., P.E.K., and K.F.H. wrote the paper.

This work was supported by the National Institutes of Health (Grant F32 DA039039 (CJS), K99 DA039791 to J.J.P., R21 MH103695 to A.R.M., R01 MH107507 to A.R.M., R01 DA024461 to P.E.K., R01 DA034231 to P.E.K. and K.F.H. 
and neurocognitive disorders collectively termed HIV-associated neurocognitive disorders or HAND) experienced by HIV patients (McArthur, 2004; Saylor et al., 2016) remain to be fully understood, the behavioral dysfunction is generally attributable to synaptodendritic injury and a loss of neuronal connectivity (Masliah et al., 1997; Ellis et al., 2007). In the post-cART era, central HIV infection is not typically characterized by evidence of gross cellular pathology (Gelman, 2015). Rather, sublethal disruptions in neuronal and glial function are beginning to be explored at the molecular level.

Aspects of the central pathology observed in HIV may reflect actions of neurotoxic viral proteins. In particular, the HIV-1 regulatory protein, trans-activator of transcription (Tat), is a soluble viral protein that can be secreted independently of cell lysis (Debaisieux et al., 2012) to exert lethal and sublethal effects on neurons via activation of inflammatory chemokines/cytokines (Langford and Masliah, 2001; D'Aversa et al., 2005); direct excitotoxic actions at glutamatergic receptors (Chandra et al., 2005; Eugenin et al., 2007; Potter et al., 2013); intracellular actions that drive $\mathrm{Ca}^{2+}$ influx via NMDA receptors, L-type $\mathrm{Ca}^{2+}$, and TRPC channels (Haughey et al., 1999; Fitting el al, 2014a, 2014b; Hu, 2016); and the generation of reactive oxidative/nitrosative species and endogenous excitotoxins (Kaul et al., 2001). The striatum has been identified as a brain region especially vulnerable to HIV.

Within the striatum, maximal viral loads are detected in the head of the caudate nucleus (Nath, 2015). Before cART, AIDS patients were notably susceptible to parkinsonian symptoms after even low exposure to antidopaminergic therapeutics (Hriso et al., 1991; Kieburtz et al., 1991; Mirsattari et al., 1998). These effects may be due in part to HIV-1 Tat as revealed by intrastriatal injections of recombinant Tat, which reduce (but do not deplete) tyrosine hydroxylase-positive cells concurrent with the onset of a parkinsonian-like response to amphetamine in rats (Zauli et al., 2000). Little is known about the distinct subsets of neurons within the striatum that may confer resilience or vulnerability to HIV protein insults throughout the striatal region. However, recent evidence in hippocampus suggests the existence of cellular subpopulations that appear to be preferentially vulnerable to Tatmediated neurotoxicity (Marks et al., 2016). Within the rodent striatum, medium spiny neurons (MSNs) comprise $90-95 \%$ of the neuronal population (Kemp and Powell, 1971; Wilson and Groves, 1980; Gerfen, 1992) and can be categorized by their expression of either dopamine subtype 1 (D1) receptors, which project directly to the internal segment of the globus pallidus and substantia nigra pars reticulata ("direct" striatal pathway), or dopamine subtype 2 (D2) receptors, which project indirectly to the internal segment of the globus pallidus and substantia nigra pars reticulata by way of the external globus pallidus. D1 and D2 MSNs have distinct morphological and electrophysiological properties (Cepeda et al., 2008; Ma et al., 2012) and are involved in a variety of functions (Graybiel, 2008).

Using animal models, we and others have observed previously that HIV-1 Tat recapitulates a neuroAIDS-like behavioral profile, promoting anxiety-like behavior (Paris et al., 2014b, 2016; Hahn

\footnotetext{
K02 DA027374 to K.F.H., R01 DA018633 to K.F.H., R01 DA033200 to K.F.H., and T32 DA007027) and the Department of Veterans Affairs (Merit Review Award 101 BX001131 to W.F.M.).

The authors declare no competing financial interests.

*C.J.S. and W.D.M. contributed equally to this work.

Kurt F. Hauser, Ph.D., Department of Pharmacology and Toxicology, Virginia Commonwealth University, Hermes

A. Kontos Medical Sciences Building, Room 439, 1217 East Marshall Street, P.0. Box 980613, Richmond, VA 232980613. E-mail: kurt.hauser@vcuhealth.org.

DOI:10.1523/JNEUROSCI.0622-17.2017

Copyright $\odot 2017$ the authors $\quad 0270-6474 / 17 / 375759-12 \$ 15.00 / 0$
}

et al., 2016), depressive-like behavior (Fu et al., 2011; Lawson et al., 2011), and motor deficits (Fitting et al., 2012; Hahn et al., 2015). These effects are dependent on the timing and duration of exposure to Tat, with central pathology preceding behavioral manifestations. The present experimental series was conducted in a timeframe when affective behavioral symptoms are burgeoning, but motor deficits are not yet manifest to better understand the synaptodendritic sequelae that underlie development of HAND. This approach allows for a more focused assessment of the neuronal deficits associated with the affective changes. We hypothesized that Tat-mediated dysregulation of the intrinsic electrophysiological properties would coincide with morphological aberrations in MSNs and provide novel insight into the nature of the behavioral pathology.

\section{Materials and Methods}

\section{Study approval}

The use of mice in these studies was preapproved by the Institutional Animal Care and Use Committee at Virginia Commonwealth University and the experiments were conducted in accordance with ethical guidelines defined by the National Institutes of Health (Publication No. 85-23).

\section{Subjects and housing}

Adult male mice ( $n=63$; $\sim 70 \mathrm{~d}$ old) expressing or lacking an HIV-1 tat transgene were described previously (Bruce-Keller et al., 2008) and were generated in the vivarium at Virginia Commonwealth University. In these mice, HIV-1 Tat $_{1-86}$ is conditionally expressed in a CNS-targeted manner via a glial fibrillary acidic protein-driven Tet-on promoter (activated via consumption of doxycycline (Dox)-containing chow; Dox Diet \#2018, 6 g/kg; Harlan Laboratories). Tat transgenic mice were bred to B6.Cg-Tg (Drd1a-tdTomato)6Calak/J line 6 mice (\#016204; The Jackson Laboratory; Ade et al., 2011) or Drd2-eGFP (\#036931-UCD; Mutant Mouse Resource and Research Centers) bacterial artificial chromosome (BAC) mice to visualize D1 and D2 striatal MSNs. Both the Drd1a-tdtomato and Drd2-eGFP BAC mice were backcrossed onto a C57BL/6 background from originating strains B6SJL (Drd1a-tdTomato) or Swiss Webster (Drd2-eGFP) by the investigators who generated the mice. All mice were housed two to five per cage and maintained in a temperature- and humidity-controlled room on a 12:12 h light-dark cycle (lights off at 18:00 h) with ad libitum access to food and water.

\section{Procedure}

Mice expressing $\left(\mathrm{Tat}^{+}\right)$, or lacking $\left(\mathrm{Tat}^{-}\right)$, the tat transgene were placed on a Dox diet for $13 \mathrm{~d}$ before testing. On day 14, mice were assessed behaviorally either for locomotion/exploratory behavior in an open field or for anxiety-like responding in a light-dark transition chamber. After either task, mice were immediately assessed for evoked motor behavior on a rotarod. On day 15 or 16, mice were euthanized and electrophysiology was performed on D1- or D2-expressing MSNs in fresh dorsal striatal (caudate/putamen) tissue. During recording, neurons were filled with biocytin for morphological assessment.

\section{Behavioral assays}

To examine the morphologic and physiologic changes accompanying affective-like disorders, mice were assessed for locomotion/exploratory behavior in an open field or for anxiety-like responding in a light-dark transition chamber. Behavior was recorded and encoded digitally by an ANY-maze behavioral tracking system (Stoelting). Although motor differences were not expected after early Tat exposure, this was confirmed by assessing evoked locomotion via rotarod testing, which was recorded via Rotamex- 5 software (Columbus Instruments). Before all behavioral testing, mice were acclimated to the testing room for $30 \mathrm{~min}$.

\section{Light-dark transition}

Anxiety-like behavior was assessed in a light-dark transition task as described previously (Crawley and Goodwin, 1980). Briefly, mice were placed in the lower left corner of the light side of a square Plexiglas box $(40 \times 40 \times 35 \mathrm{~cm}$, evenly divided into light and dark compartments; Stoelting) and allowed to explore for $10 \mathrm{~min}$. Shorter latencies to transi- 
tion to the dark compartment and less time spent in the light compartment were considered indices of greater anxiety-like behavior.

\section{Open field}

Spontaneous locomotion was assessed in an open field as described previously (Hall and Ballachey, 1932). Briefly, mice were placed in the lower left corner of a square Plexiglas box $(40 \times 40 \times 35 \mathrm{~cm}$; Stoelting $)$ and allowed to explore for $30 \mathrm{~min}$. The average speed and total distance traveled, time spent mobile, as well as the time spent rearing, were used as indices of motor/exploratory behavior.

\section{Rotarod}

Evoked locomotion was assessed in a series of rotarod tests as described previously (Paris et al., 2013; Hahn et al., 2016). Briefly, mice were required to balance on an immobile rotarod $(3 \mathrm{~cm}$ in diameter and suspended $44.5 \mathrm{~cm}$ high; Columbus Instruments) for $30 \mathrm{~s}$. Two $30 \mathrm{~s}$ fixed-speed trials $(10 \mathrm{rpm})$, followed by two $180 \mathrm{~s}$ fixed speed trials (10 $\mathrm{rpm}$ ), were conducted for training. Lastly, mice were tested on two accelerating speed trials ( $180 \mathrm{~s}$ maximum latency at $0-20 \mathrm{rpm}$ ). Some mice were further assessed in two additional accelerating speed trials with a higher performance ceiling (180 s maximum latency at $0-40 \mathrm{rpm}$ ). The mean latency to fall from the rotarod and the maximum rpm achieved across the two accelerated trials were used as indices for evoked locomotion. Decreased latencies to fall and lower maximal rpm achieved on the accelerating tests indicated impaired locomotion.

\section{Electrophysiological recording}

Adult male mice expressing either $\mathrm{D} 1_{\text {tdTomato }}$ or $\mathrm{D} 2_{\mathrm{eGFP}}$ were transcardially perfused with calcium-free sucrose cutting medium containing the following (in mM): $3 \mathrm{KCl}, 4.12 \mathrm{MgSO}_{4}, 1.2 \mathrm{NaH}_{2} \mathrm{PO}_{4}, 206$ sucrose, 25 $\mathrm{NaHCO}_{3}$, and 25 glucose oxygenated using a $5 \% \mathrm{CO}_{2}$ balanced oxygen mixture. Brains were extracted and cut coronally on a Leica VT1200 S vibratome in $350 \mu \mathrm{m}$ sections while submerged in oxygenated sucrose cutting medium held at $1-3^{\circ} \mathrm{C}$ by an external cooling apparatus (Huber). Slices were transferred to a beaker with oxygenated extracellular recording solution containing the following (in $\mathrm{mm}$ ): $125 \mathrm{NaCl}, 3 \mathrm{KCl}, 1.2$ $\mathrm{CaCl}_{2}, 1.2 \mathrm{MgSO}_{4}, 1.2 \mathrm{NaH}_{2} \mathrm{PO}_{4}, 25 \mathrm{NaHCO}_{3}$, and 25 glucose, returned to room temperature, and allowed to rest for $30 \mathrm{~min}$ before recording.

\section{Stimulation and recording protocol}

Slices were visualized at $4 \times$ magnification on a Zeiss Axio Examiner A1 microscope to verify the location of the striatum. Striatal neurons were identified using a $63 \times$ water-immersion objective. $\mathrm{D} 1_{\mathrm{tdTomato}}{ }^{-}$or $\mathrm{D} 2_{\mathrm{eGFP}}$-expressing neurons were identified using LED illumination (UHP-T-LED; Prizmatix) and filters for green (470/40 nm excitation, 495 dichroic, 525/50 nm emission; filter set 38, catalog \#000000-1031346; Zeiss) and red (filter set XF140-2, Omega Optical) wavelengths. Recordings were obtained using borosilicate glass pipettes (2-6 M $\Omega$; WPI catalog \#1B1505-4) pulled on a Narishige PC-10 pipette puller, and filled with an intracellular solution containing the following (in mM): 135 $\mathrm{KMeSO}_{4}, 10$ HEPES, $2 \mathrm{MgATP}, 0.1 \mathrm{MgGTP}, 8 \mathrm{NaCl}$, and 0.1 BAPTAK4, biocytin $0.2 \%, \mathrm{pH}$ 7.25. Membrane potentials were recorded using a MultiClamp 700B amplifier (Molecular Devices), a Digidata 1550A digitizer (Molecular Devices), and Clampex 10.4 software (Molecular Devices) configured to a Windows 7-based PC. The passive and active electrical membrane properties were assessed by injecting hyperpolarizing and depolarizing current steps of $50 \mathrm{pA}$ ranging from -100 to 450 pA. Analyses were performed using Clampfit 10.4 (Molecular Devices).

\section{Morphological assessment}

Histology. After patch-clamp experiments, slices containing biocytinfilled neurons were fixed using $4 \%$ paraformaldehyde in $1 \times$ PBS for 4-7 $\mathrm{d}$ at $4^{\circ} \mathrm{C}$. Slices were then rinsed six times in PBS for $10 \mathrm{~min}$ on a rocking platform. Fluorescent probes conjugated to streptavidin were used to identify biocytin-filled neurons. Slices were placed in a PBS solution containing $0.04 \%$ Triton X-100 and a 1:500 dilution of the streptavidinconjugated probe. $\mathrm{D} 1_{\text {tdTomato }}$-expressing MSNs were marked with Alexa Fluor 488 (Thermo Fisher Scientific, catalog \#S32354), and D2 GFP $^{-}$ expressing MSNs with Alexa Fluor 594 (Thermo Fisher Scientific. catalog \#S32356) to differentiate the biocytin-filled target neuron from D1- or
D2-expressing MSNs not being assessed. Slices remained in these solutions for $2-3 \mathrm{~d}$ at $4^{\circ} \mathrm{C}$ on a rocking platform and were then rinsed as above. Slices were mounted on slides using ProLong Gold Antifade reagent (Invitrogen, catalog \#P36930).

$3 D$ reconstruction and neurite analysis. $Z$-stack imaging of neurons was performed using a Zeiss LSM 700 at $20 \times(0.8$ numerical aperture, NA) or $63 \times$ magnification $(1.40 \mathrm{NA})(34 \mu \mathrm{m}$ pinhole $=1$ airy unit; Zeiss objectives). $Z$-stack data were reconstructed into $3 \mathrm{D}$ images using the Bitplane Imaris 7.6.4 neuroscience analysis software package. Primary dendrites were determined as emanating directly from the cell body and dendritic order increased distally at every branch point. Dendritic complexity of individual neurons was assessed by Scholl analysis using 2D maximumintensity projections of the $Z$-stack images. Dendritic spine analyses were performed on $20-30 \mu \mathrm{m}$ dendritic segments that were $\geq 5 \mu \mathrm{m}$ distant from the proximal and distal branch points. Dendritic spine densities are reported as the average number of spines per $10 \mu \mathrm{m}$ length of dendrite. Spine density and dendritic integrity were averaged from $\sim 4$ segments each from second-, third-, and fourth-order dendrites for each neuron and constituted separate $(n=1)$ observations. Different morphologic types of dendritic spines were assessed using uncompressed $Z$-stacks. Dendritic spines were categorized as thin, stubby, or mushroom shaped (Harris et al., 1992; Ochs et al., 2015) and each type was counted and reported as a percentage of total spines. The proportion of each spine type was determined from one or more dendritic segments $(\sim 30 \mu \mathrm{m}$ total) in segments oriented parallel to the plane of the slice for each neuron.

\section{Statistical analyses}

For the patch-clamp neurophysiologic and corresponding morphologic studies, biocytin-filled neurons were uniformly sampled from at least five mice per experimental group such that no more than three neurons were sampled from an individual mouse. Dependent measures on morphology were assessed via Student's two-tailed $t$ tests with genotype (Tat ${ }^{-}$or $\mathrm{Tat}^{+}$) as the between-subjects factor, apart from the Scholl analyses, which were assessed via repeated-measures ANOVA with genotype $\left(\mathrm{Tat}^{-}\right.$or Tat $^{+}$) and crossings as the between- and within-subjects factors, respectively. Simple linear regressions were used to discern the amount of variance in dendritic damage that could be explained by changes in neurite morphology. Firing frequency was assessed via repeated-measures ANOVA with genotype ( $\mathrm{Tat}^{-}{ }^{-}$or Tat ${ }^{+}$) and current steps $(200-450 \mathrm{pA})$ as the between- and within-subjects factors, respectively. Intrinsic physiological properties were analyzed by one-way ANOVA. For behaviorally dependent measures, no significant differences were observed between $\mathrm{Tat}^{-}$or Tat $^{+}$mice that were crossed to equivalent numbers of Drd1a-tdTomato versus those crossed to Drd2eGFP reporter mice; therefore, groups were collapsed on reporter condition and analyzed by Tat genotype condition via Student's two-tailed $t$ tests. Fisher's protected least significant difference post hoc tests determined group differences following main effects. Interactions were delineated via simple main effects and main effect contrasts with the error controlled for multiple comparisons. Analyses were considered significant when $p<0.05$.

\section{Results}

\section{D2 MSNs demonstrated selective vulnerability to HIV-1} Tat-induced dendritic damage, but not loss of complexity Dendrites and dendritic spines were readily visualized in biocytinfilled D1-expressing (Fig. $1 A, C, E$ ) or D2-expressing (Fig. $1 B, D, F$ ) MSNs. Importantly, Tat expression did not elicit global changes in the gross appearance of MSNs (Fig. 1E,F) in either dendritic complexity (Fig. $1 G, H)$ or length (Fig. $1 I)$ among D1 $(n=9$ neurons, $5 \mathrm{Tat}^{-}$mice; $n=8$ neurons, $6 \mathrm{Tat}^{+}$mice) or D2 ( $n=9$ neurons, $8 \mathrm{Tat}^{-}$mice; $n=15$ neurons, $8 \mathrm{Tat}^{+}$mice) MSNs in 3D reconstructed images (Fig. $1 C, D)$.

An analysis of dendritic spines (Fig. 2) revealed no significant changes in dendritic spine density (Fig. $2 A, A^{\prime}, C$ ) or the percentage of damaged dendrites (Fig. 2I) among D1 neurons. D2 MSNs were, however, selectively vulnerable to HIV-1 Tat-induced den- 

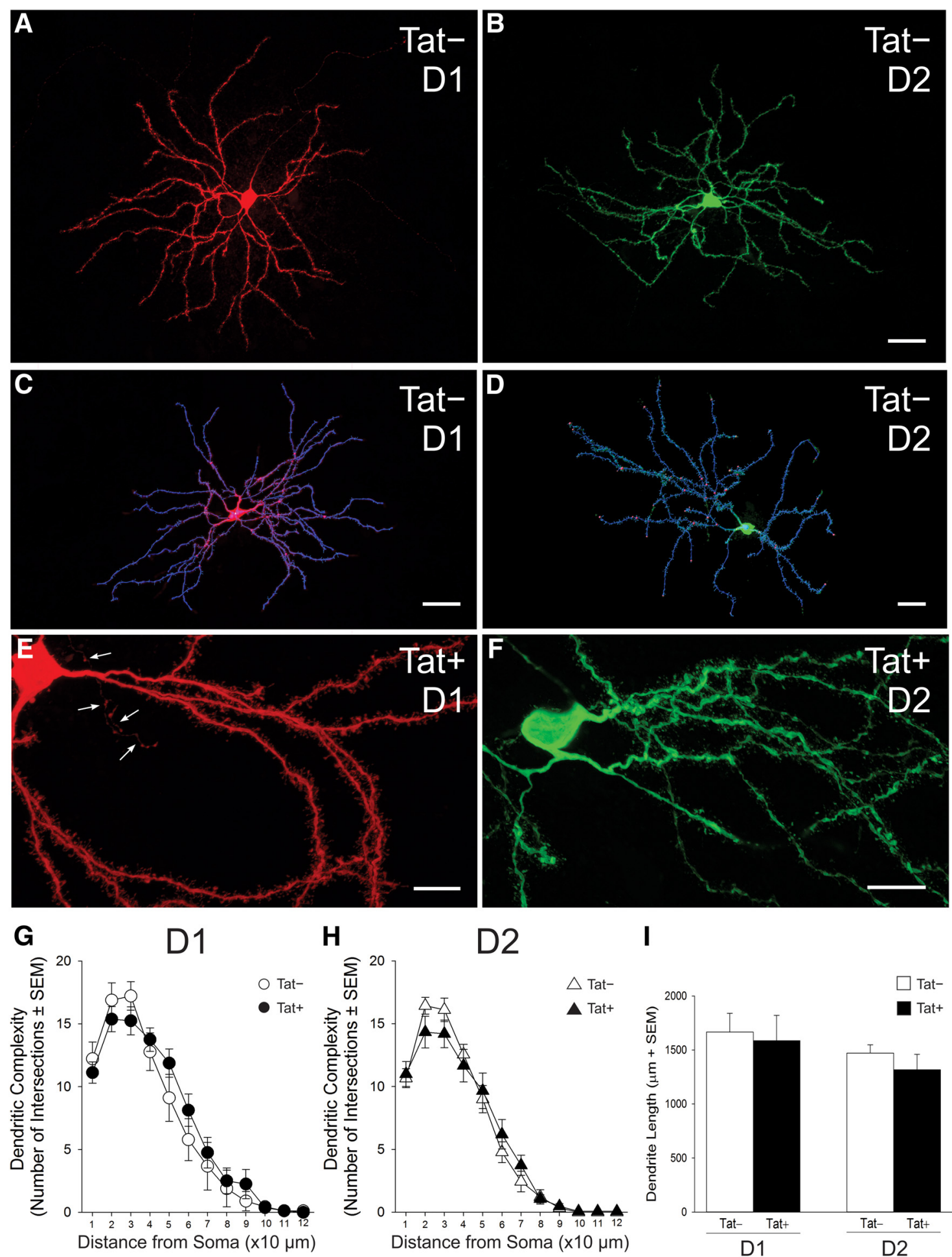

I

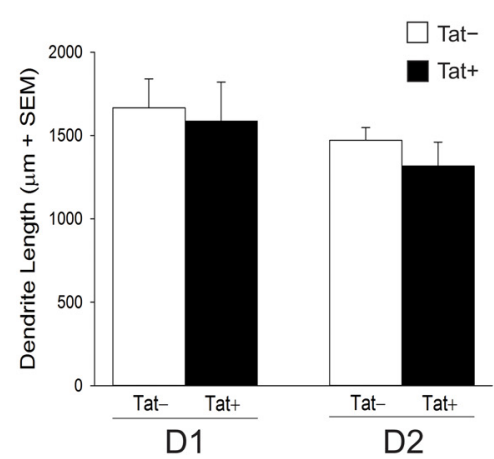

Figure 1. Structure of $D 1$ and $D 2$ receptor-expressing striatal $M S N s$ in Tat ${ }^{-}$and Tat $^{+}$transgenic mice. $A-F, D 1(A, C, E)$ and D2 $(B, D, F) M S N s$ were identified via expression of tdTomato or eGFP, respectively, and filled with biocytin for morphological assessment; a filled axon is shown in $\boldsymbol{E}$ (arrows). C, D, Biocytin-filled neurons were reconstructed in 3D from sequential, Z-stacked, confocal images and their dendritic complexity was analyzed using Bitplane Imaris software (version 7.6.4). $\mathbf{G}-\boldsymbol{I}$, Dendritic complexity $(\mathbf{G}, \boldsymbol{H})$ and overall length $(\boldsymbol{I})$ as estimated using Scholl analysis did not differ significantly between Tat $^{+}$and Tat ${ }^{-}$transgenic mice in either D1 (G) or D2 (H) MSNs. Scale bars: $\boldsymbol{A}, \boldsymbol{B}, 10 \mu \mathrm{m} ; \boldsymbol{C}, \boldsymbol{D}, 30 \mu \mathrm{m}$; and $\boldsymbol{E}, \boldsymbol{F}, 5 \mu \mathrm{m}$.

dritic damage. Tat-exposed D2 MSNs ( $n=16$ neurons, 8 mice) exhibited significantly reduced third-order $\left(t_{(23)}=3.23, p<\right.$ $0.05)$ and fourth-order $\left(t_{(23)}=1.92, p<0.05\right)$, but not secondorder, dendritic spine density (Fig. 2D). A greater proportion of D2 MSN dendrites also showed structural damage (Fig. $2 \mathrm{~F}-\mathrm{H}$ ) as determined by the presence of swellings/varicosities in second- order $\left(t_{(23)}=1.95, p<0.05\right)$, third-order $\left(t_{(23)}=3.38, p<0.05\right)$, and fourth-order $\left(t_{(23)}=3.45, p<0.05\right)$ dendrites, compared with Tat $^{-}(n=9$ neurons, 6 mice) controls (Fig. $2 J)$, although many displayed normal morphology (Fig. 2E). Additional analyses of spine morphology were conducted to determine the proportion of mushroom-, stubby-, and thin-shaped spines as- 
sociated with D1 ( $n=7$ neurons, 5 Tat $^{-}$ mice; $n=7$ neurons, $6 \mathrm{Tat}^{+}$mice) and D2 ( $n=7$ neurons, 6 Tat $^{-}$mice; $n=14$ neurons, $7 \mathrm{Tat}^{+}$mice) MSN dendrites (Fig. 3). Compared with $\mathrm{Tat}^{-}$controls, $\mathrm{Tat}^{+}$ mice demonstrated a significant $\left(F_{(1,19)}=\right.$ $4.452, p<0.05)$ decrease in the proportion of thin spines, and a significant $\left(F_{(1,19)}=5.402, p<0.05\right)$ increase in the proportion of stubby spines on D2 MSNs (Fig. 3C, E, G). No significant differences were observed in the proportion of D2 mushroom spines (Fig. $3 G$ ) or the proportion of any morphological spine subtype on D1 MSNs (Fig. 3F). Linear regressions revealed that the proportion of thin $\left(R^{2}=0.33, F_{(1,20)}=9.44, p<\right.$ $0.05)$ and stubby $\left(R^{2}=0.24, F_{(1,20)}=\right.$ $6.12, p<0.05$ ) spines (but not mushroom spines) significantly accounted for variance in the proportion of damaged D2 neurons. No significant differences were observed in D1 MSNs.

HIV-1 Tat increased the excitability of D2, but not D1, MSNs

Electrophysiological recordings from D1 MSNs ( $n=9-10$ neurons, 6 Tat $^{-}$mice; $n=10-11$ neurons, $5 \mathrm{Tat}^{+}$mice) revealed no differences in measures of excitability or intrinsic physiological properties after Tat induction (Fig. 4, Table 1). Exposure to Tat caused a significant, biphasic shift in the excitability of D2 MSNs ( $n=14$ neurons, 6 mice) compared with recordings from D2 MSNs of Tat ${ }^{-}$animals $(n=14$ neurons, 6 mice $)\left(F_{(1,26)}=8.916, p<\right.$ 0.05) (Fig. $4 A^{\prime}, B^{\prime}$ ). Firing frequency was decreased in Tat ${ }^{+}$MSNs at current levels between 200 and $300 \mathrm{pA}(p=0.0005-$ $0.03)$ and increased at $450 \mathrm{pA}(p=0.03)$, with no differences in frequency observed at midrange current sweeps (350-400 pA; Fig. $4 C^{\prime}$ ). A commensurate increase in rheobase was observed in $\mathrm{Tat}^{+} \mathrm{D} 2 \mathrm{MSNs}$ ( $n=14$ neurons, 6 mice) compared with Tat ${ }^{-}$controls ( $n=14$ neurons, 6 mice) $\left(F_{(1,26)}=9.420, p<0.05\right)$ (Fig. $4 C^{\prime}$, inset). A reduction in the input resistance of $\mathrm{Tat}^{+}$D2 MSNs $\left(n=14\right.$ neurons, $6 \mathrm{Tat}^{+}$ mice; $n=14$ neurons, 6 Tat $^{-}$mice) was also observed $\left(F_{(1,26)}=6.563, p<0.05\right)$ (Table 1).

\section{Anxiety-like (but not locomotor)}

behavior was increased, whereas exploratory behavior decreased with HIV-1 Tat exposure

Exposure to Tat significantly increased anxiety-like behavior of mice and reduced exploratory behavior. In the light-dark transition task, Tat $^{+}$mice $(n=17)$ demonstrated a significantly lower latency to
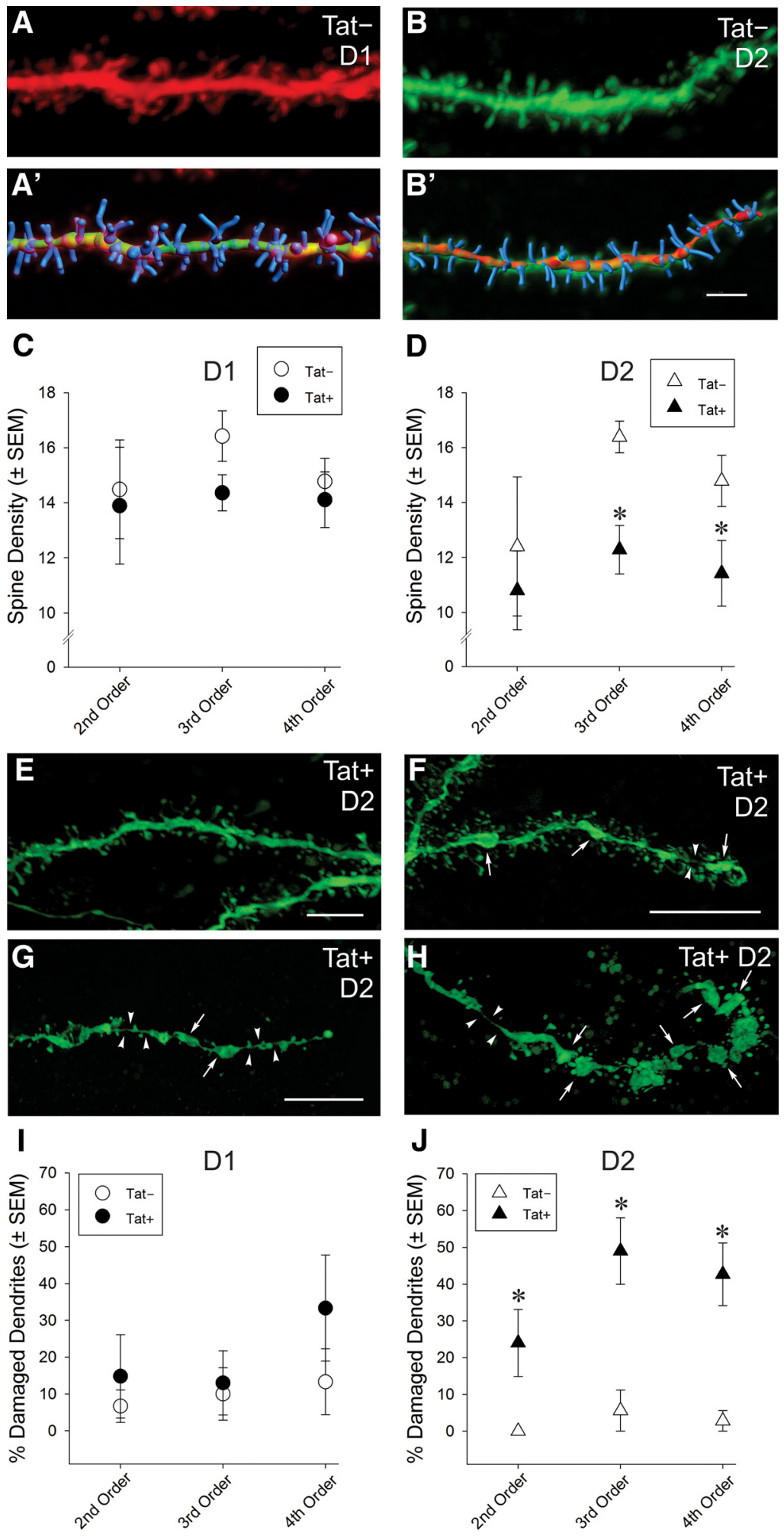

Figure 2. A-J, Synaptodendritic structure of D1 and D2 receptor-expressing striatal MSNs in $\mathrm{Tat}^{-}$and $\mathrm{Tat}^{+}$transgenic mice. No differences in dendritic spine density were observed in D1 MSNs between Tat ${ }^{+}$and Tat ${ }^{-}$transgenic mice $\left(\boldsymbol{A}, \boldsymbol{A}^{\prime}, \boldsymbol{C}\right)$; however, $\mathrm{Tat}^{+}$mice had significantly lower dendritic spine density in D2 MSNs compared with Tat ${ }^{-}$mice $\left(\boldsymbol{B}, \boldsymbol{B}^{\prime}, \boldsymbol{D}\right) . \boldsymbol{A}^{\prime}, \boldsymbol{B}^{\prime}$, Superimposed, Bitplane Imaris $3 D$ reconstructions of the same dendrites as in $A$ and $\boldsymbol{B}$. Scale bar, $3 \mu \mathrm{m}$. ${ }^{*}$ Significant main effect of genotype, $p<$ $0.05(\boldsymbol{D}) . \boldsymbol{E}-\boldsymbol{J}$, Compared with dendrites of D2 MSNs in Tat ${ }^{-}$mice $(\boldsymbol{B}, \boldsymbol{I})$, a significantly greater proportion of dendrites in Tat ${ }^{+}$ mice displayed swellings/varicosities (arrows) and thinning (arrowheads) of the main axis of the dendrite indicative of dendritic damage and/or pending fragmentation $(\boldsymbol{F}-\boldsymbol{H})$, although dendrites with normal morphology lacking swelling/varicosities could also be found on D2 MSNs (E). Images in $\boldsymbol{E}$ - $\boldsymbol{H}$ were sharpened (Gaussian blur) and median gray levels adjusted in Adobe Photoshop CS6 to better illustrate subtle boundaries, especially those associated with regions of dendritic thinning. Scale bar, $3 \mu \mathrm{m}(\boldsymbol{F}, \boldsymbol{H}$ are the same scale). * Significant main effect of genotype, $p<0.05(J)$. 


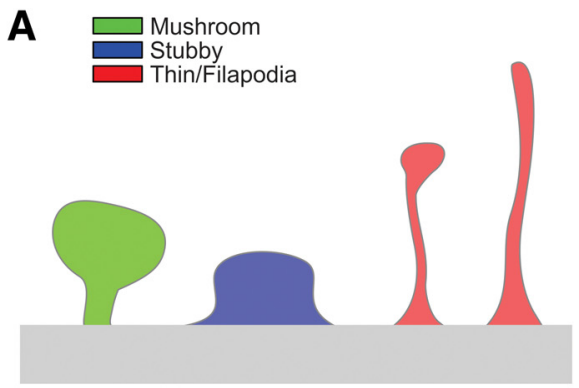

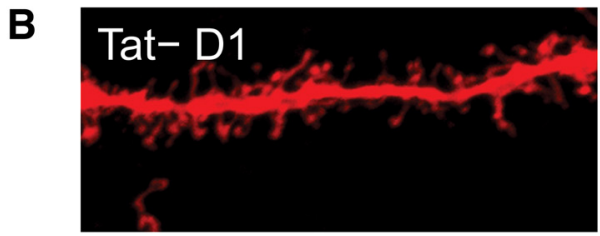

D

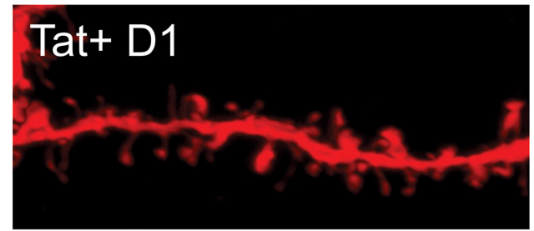

\section{$\mathbf{F}$}

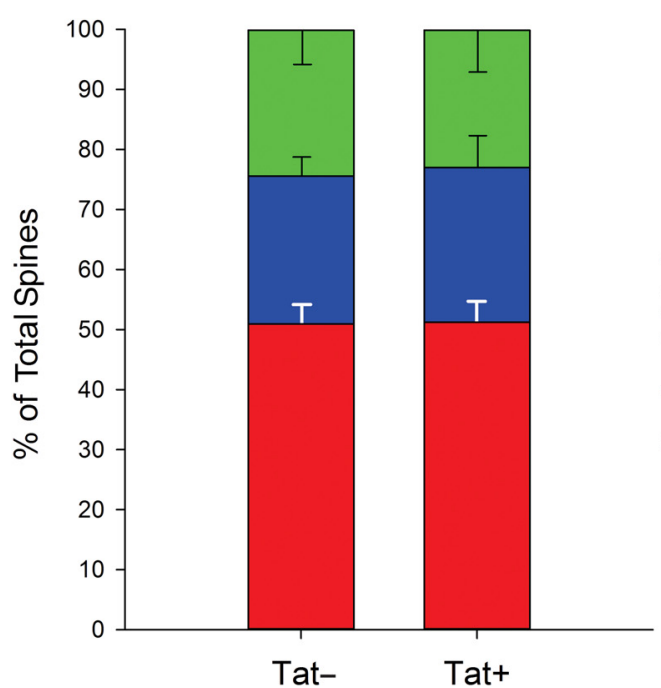

C

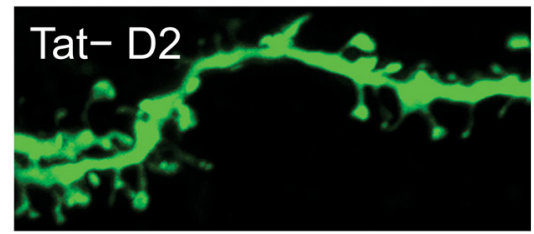

E

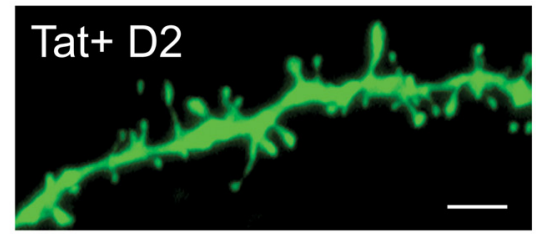

G
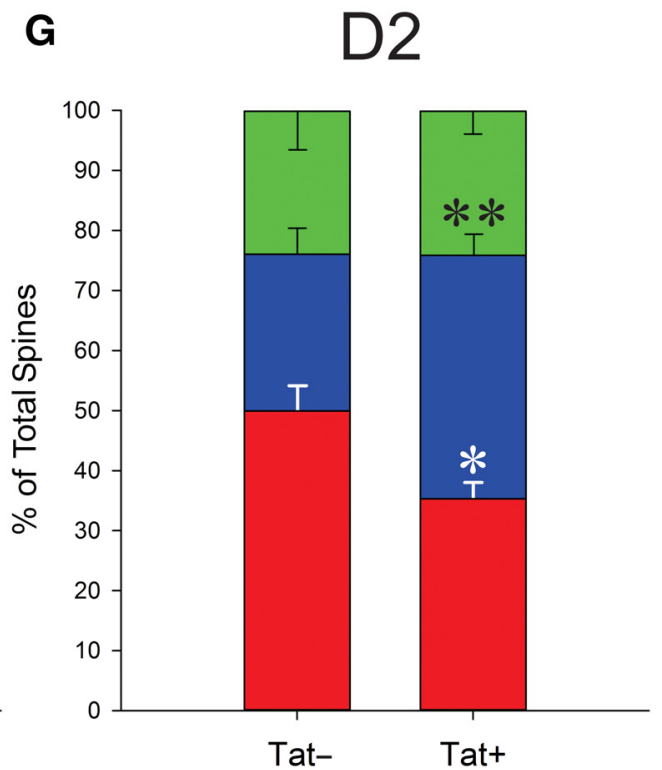

Figure 3. A, Depiction of the three classifications of dendritic spines assessed in this study. $\boldsymbol{B}-\boldsymbol{E}$, Representative dendrite segments from Tat ${ }^{-}(\boldsymbol{B}){\text { and } \text { Tat }^{+}(\boldsymbol{D}) \mathrm{D1}^{\mathrm{MSN}} \mathrm{\text {andfromTat }}{ }^{-}(\boldsymbol{C}) \text { and }}$ $\mathrm{Tat}^{+}(\boldsymbol{E})$ D2 MSNs showing various dendritic spine morphologies. Scale bar, $3 \mu \mathrm{m}$. $\boldsymbol{F}, \mathbf{G}$, Percentage of morphologic spine types on D1 MSN dendrites was unchanged between Tat ${ }^{+}$and Tat ${ }^{-}$ animals $(\boldsymbol{F})$, whereas the percentage of filopodia/thin-shaped spines on D2 MSN dendrites was decreased in Tat ${ }^{+}$animals $\left({ }^{*} p<0.05\right)$, the percentage of stubby spines increased (** $\left.p<0.05\right)$, and the proportion of mushroom-shaped spines was unchanged compared with Tat ${ }^{-} \operatorname{controls~(G).~}$

escape the light chamber after Dox-induced induction of Tat expression compared with Tat ${ }^{-}$mice $(n=16)\left(t_{(31)}=2.81, p<0.05\right)$ (Fig. 5A) and made significantly more transitions between the light and dark chambers $\left(t_{(31)}=2.06, p<0.05\right)$ (Fig. 5B). Moreover, exploratory behavior was decreased in an open field because $\mathrm{Tat}^{+}$mice $(n=18)$ spent significantly less time rearing after Dox administration than did Tat ${ }^{-}$controls $(n=14)\left(t_{(31)}=2.06, p<\right.$ 0.05 ) (Fig. 5C), although no difference was observed for the amount of time spent exploring the center field (Table 2). These effects are not thought to be due to differences in motor phenotype given that mice did not differ in the distance traveled within an open field (Fig. 5D) or evoked locomotor performance on a rotarod (Table 2). Mice also did not differ on other behavioral measures (Table 2). There was no baseline difference between Drd1a-tdTomato and Drd2-eGFP mice in the behavioral outcomes measured in the present study (data not shown).

\section{Discussion}

Dendritic complexity and length of D1 or D2 MSNs were unaffected by short-term (2 weeks) exposure to HIV-1 Tat, which differs markedly from the pronounced MSN damage seen after 3 months of Tat induction in male mice (Hahn et al., 2015). In contrast, subtler patterns of synaptodendritic injury were evident at $14 \mathrm{~d}$, especially in D2 MSNs, whereas little to no effects were 


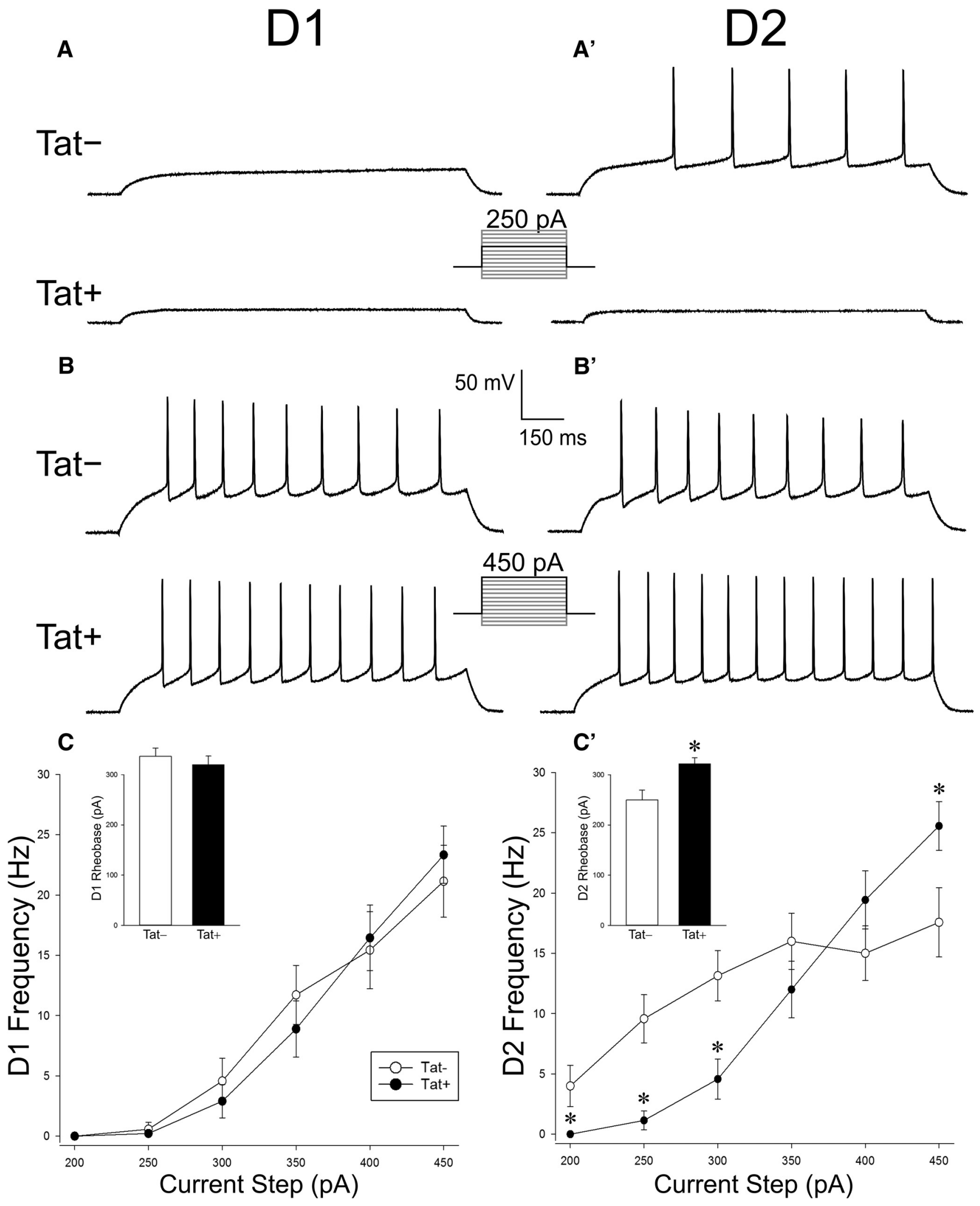

Figure 4. $\boldsymbol{A}-\boldsymbol{B}^{\prime}$, Representative traces from electrophysiological recordings of $\mathrm{D} 1(\boldsymbol{A})$ and $\mathrm{D} 2\left(\boldsymbol{A}^{\prime}\right)$ striatal MSNs at $250 \mathrm{pA}\left(\boldsymbol{A}, \boldsymbol{A}^{\prime}\right)$ or $450 \mathrm{pA}\left(\boldsymbol{B}, \boldsymbol{B}^{\prime}\right)$ of current. $\boldsymbol{C}$, No differences were observed in the frequency of action potential firing or rheobase (C, inset) in D1 MSNs of mice that expressed the HIV-1 Tat transgene (Tat ${ }^{+}$) or their control counterparts (Tat ${ }^{-}$). $\boldsymbol{C}^{\prime}$, However, MSNs in Tat ${ }^{+}$mice demonstrated a significantly reduced frequency of action potentials while stimulating at $200-350 \mathrm{pA}$ and a significantly greater frequency of action potentials at $450 \mathrm{pA}$ in D2 MSNs compared with Tat $^{-}$MSNs. D2 MSN rheobase values were significantly greater in Tat ${ }^{+}$compared with Tat ${ }^{-}$, mice $\left(\boldsymbol{C}^{\prime}\right.$, inset). ${ }^{*}$ Significant difference from Tat ${ }^{-}$following a significant interaction of genotype and stimulus current ( $\mathrm{pA})$ intensity, $p<0.05$. 
Table 1. Intrinsic electrophysiological properties of D1 and D2 striatal medium spiny neurons from HIV-1 Tat $^{+}$transgenic and Tat ${ }^{-}$control mice

\begin{tabular}{|c|c|c|c|c|}
\hline & \multicolumn{2}{|l|}{ D1 MSNs } & \multicolumn{2}{|l|}{ D2 MSNs } \\
\hline & $\begin{array}{l}\mathrm{Tat}^{-} \\
(n=9-10)\end{array}$ & $\begin{array}{l}\text { Tat }^{+} \\
(n=10-11)\end{array}$ & $\begin{array}{l}\mathrm{Tat}^{-} \\
(n=13-14)\end{array}$ & $\begin{array}{l}\text { Tat }^{+} \\
(n=14)\end{array}$ \\
\hline$V_{R}(\mathrm{mV})$ & $-83.0 \pm 0.7$ & $-86.7 \pm 0.6$ & $-84.1 \pm 0.7$ & $-84.7 \pm 0.5$ \\
\hline Capacitance (pF) & $31.8 \pm 4.4$ & $23.2 \pm 4.5$ & $34.2 \pm 3.9$ & $32.3 \pm 3.1$ \\
\hline Input resistance ( $\mathrm{M} \Omega$ ) & $38.1 \pm 4.3$ & $40.0 \pm 4.3$ & $56.3 \pm 6.3$ & $36.7 \pm 4.3^{*}$ \\
\hline $\begin{array}{l}\text { Action potential } \\
\text { threshold }(\mathrm{mV})\end{array}$ & $-37.9 \pm 1.4$ & $-39.7 \pm 1.1$ & $-40.0 \pm 1.1$ & $-41.0 \pm 1.2$ \\
\hline $\begin{array}{l}\text { Action potential } \\
\text { amplitude }(\mathrm{mV})^{\mathrm{a}}\end{array}$ & $80.6 \pm 2.0$ & $82.0 \pm 2.4$ & $88.2 \pm 1.9$ & $85.5 \pm 1.3$ \\
\hline
\end{tabular}

No significant differences were observed in the intrinsic properties of D1 MSNs.

*Significant main effect of Tat genotype, $p<0.05$.

${ }^{a}$ Amplitude of the first action potential evoked by a $450 \mathrm{pA}$ depolarizing current injection. Amplitudes were measured from action potential threshold to peak.

observed in D1 MSNs. Tat effects in D2, but not D1, MSNs agree with our previous findings that $7 \mathrm{~d}$ of Tat expression significantly reduces dendritic spine density in Golgi-impregnated MSNs (Fitting et al., 2010). Because the Golgi procedure cannot discern neurochemically distinct MSN subpopulations, the present findings suggest our earlier findings were solely due to deficits in D2 MSNs. Perturbations in D2 MSNs were associated with an increased anxiety-like behavioral profile. These results were somewhat unexpected because HIV patients can display parkinsonian-like symptomatology that can be treated with dopamine agonists (Nath et al., 2000) and are typically associated with deficits in D1 MSNs comprising the direct striatal pathway (Gerfen, 1992; Gerfen and Wilson, 1996). However, such patients have likely experienced long-term exposure to Tat, additional neurotoxic viral proteins, and local inflammation, with resulting damage to D1 MSNs and their associated circuitry. The amount of overall MSN degeneration is much greater after 3 months of Tat induction in mice (Hahn et al., 2015) compared with 2 weeks of induction, as seen in the present study. Future studies exploring whether D2 MSN deficits can be reversed by turning off Tat expression or prevented by, for example, D2 receptor agonists, may be warranted.

Striatal D2 MSNs are more vulnerable to kainic acid-mediated cell death (Mesco et al., 1992) and typically more excitable than their D1 MSN counterparts (Cepeda et al., 2008), which is commensurate with an enhanced vulnerability to the excitotoxic effects of Tat. Moreover, genetic studies in humans (Sanna et al., 2016) and HIV transgenic rats (Repunte-Canonigo et al., 2014) show patterns consonant with synaptodendritic injury in Huntington's disease, which is characterized by altered dopaminergic neurotransmission (Jakel and Maragos, 2000) and decreased numbers of D2-expressing MSNs (Augood et al., 1997). Importantly, the preferential loss of dendritic spines on D2-expressing MSNs may not result in diminished output from the indirect pathway. In fact, Tat had opposing effects on D2 MSN excitability depending on the amount of current applied, indicating complex actions on D2 MSNs. Although some findings question the canonical model of opposing, parallel direct/indirect pathways in favor of a model in which D1- and D2-expressing MSNs act interdependently through intrastriatal connections (Calabresi et al., 2014), other recent evidence suggests that the classic model remains valid depending on the outcome measured (Lee et al., 2016). Our findings indicate that Tat dysregulates the D2expressing, indirect pathway preferentially, which is likely to disrupt the dynamic interrelationship between D1 and D2 MSNs and trigger imbalances in striatal function.
Despite differences in etiology, there are similarities between Parkinson's disease and the hypokinetic movement disorders observed in HIV-1 patients (DeVaughn et al., 2015). In cART-naive cohorts, observations of increased CSF dopamine and reduced dopamine turnover to its metabolites have been reported (Larsson et al., 1991; Berger et al., 1994; di Rocco et al., 2000; Scheller et al., 2010). Increased levels of dopamine and its metabolites correlate with neuropsychological impairment and reduced CD4 counts in HIV patients (Obermann et al., 2009; Scheller et al., 2010). However, genetic polymorphisms may influence these observations (Horn et al., 2013; Koutsilieri et al., 2014). HIV proteins, including Tat and gp120 (Agrawal et al., 2010), can modulate dopamine and HIV-1 Tat induces excitotoxicity in MSNs (Silvers et al., 2007; Zhou and Saksena, 2013; Fitting el al, 2014a, 2014b). Therefore, Tat appears to affect both dopamine levels and the excitability of MSNs directly.

The intrinsic electrophysiological properties of D2 MSNs may confer vulnerability to Tat effects. D1 and D2 MSNs have divergent anatomical and physiological properties reflecting differential cortical inputs, with D2-expressing MSNs being more excitable and mirroring cortical activity more closely (Cepeda et al., 2008; Gertler et al., 2008; Lee et al., 2016). As noted earlier, D2-expressing neurons are reportedly more vulnerable to excitotoxic insults (Mesco et al., 1992). This increased excitability is observed in the dendrites of D2 MSNs, in which single backpropagating action potentials produce increased calcium influx more reliably and at a greater distance from the soma than D1 MSNs. In cultured MSNs treated with Tat, intradendritic calcium levels were increased compared with controls, suggesting that normally high $\left[\mathrm{Ca}^{2+}\right]_{\mathrm{i}}$ in D2 MSNs is further increased by Tat (Day et al., 2008; Fitting el al., 2014a). Excitatory and inhibitory inputs to the striatum are modulated differentially by D1 or D2 receptor activation, respectively, with $\mathrm{D} 1$ receptors potentiating NMDA signaling (Chergui and Lacey, 1999; Brady and O'Donnell, 2004; Tseng and O'Donnell, 2004). HIV-1 Tat can inhibit dopamine transporter function allosterically (Zhu et al., 2009; Midde et al., 2013), potentially elevating extracellular dopamine content. Collectively, Tat-induced alterations in extracellular dopamine may exacerbate its excitotoxic effects. In support, blocking D1 or NMDA receptors protects against HIV-1 Tatmediated neurotoxicity (Aksenov et al., 2006, 2012; Silvers et al., 2007). Although a subset of MSNs express both D1 and D2 receptors (Gerfen, 1992; Bertran-Gonzalez et al., 2008; Matamales et al., 2009), the proportion coexpressing D1 and D2 is $\leq 7 \%$ in the dorsal striatum (Perreault et al., 2010, 2011).

Synaptodendritic injury coincided with physiological disturbances in D2 MSNs (Cepeda et al., 2008; Gertler et al., 2008, Lee et al., 2016). We speculate that synaptodendritic injury is largely due to Tat-driven calcium influx into the dendrites of D2 MSNs, which generally display greater $\left[\mathrm{Ca}^{2+}\right]_{\mathrm{i}}$ than D1 MSNs (Day et al., 2008). Although functional deficits cannot be associated causally with spine loss, there is a link between spine loss and parkinsonian-like symptoms in neuroAIDS (Cardoso, 2002; Tse et al., 2004; Villalba and Smith, 2013).

In addition to direct actions on MSNs, Tat may affect intrinsically neurons projecting to the striatum from other brain regions, as well as intrastriatal interneurons, which could modulate direct/indirect striatal pathways beyond that predicted from simple models of basal ganglia function (Day et al., 2008; Chuhma et al., 2011; Blomeley et al., 2015; Marks et al., 2016). In agreement, Tat exposure did not affect the firing frequency of D1-expressing MSNs, whereas D2-expressing MSNs responded biphasically. This imbalance between D1 and D2 outputs is likely to disrupt 
A

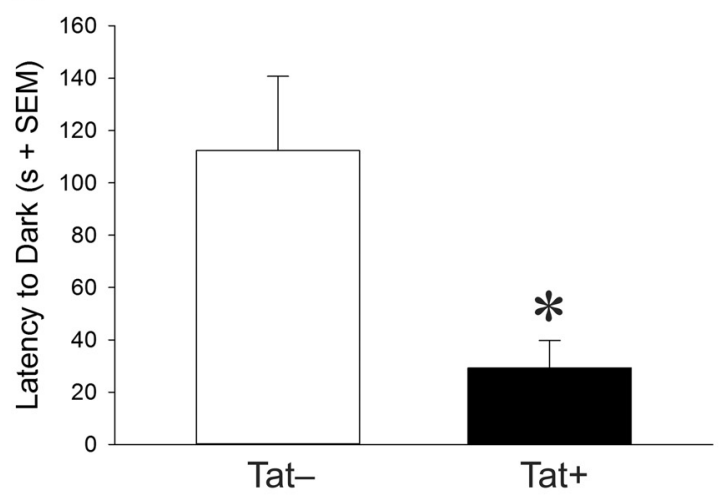

C

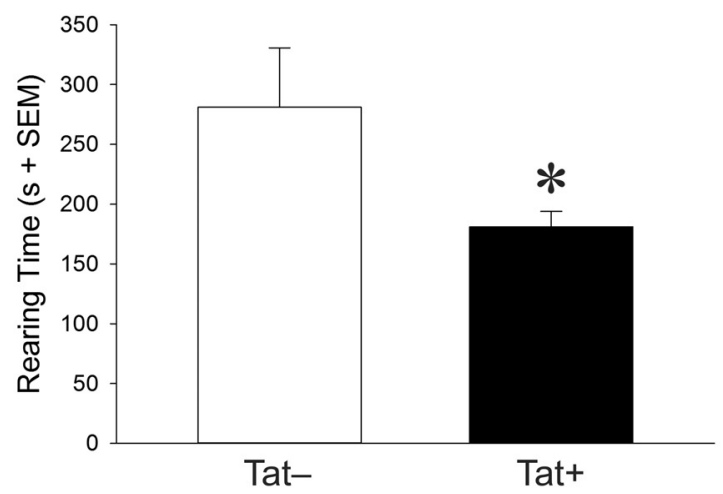

B
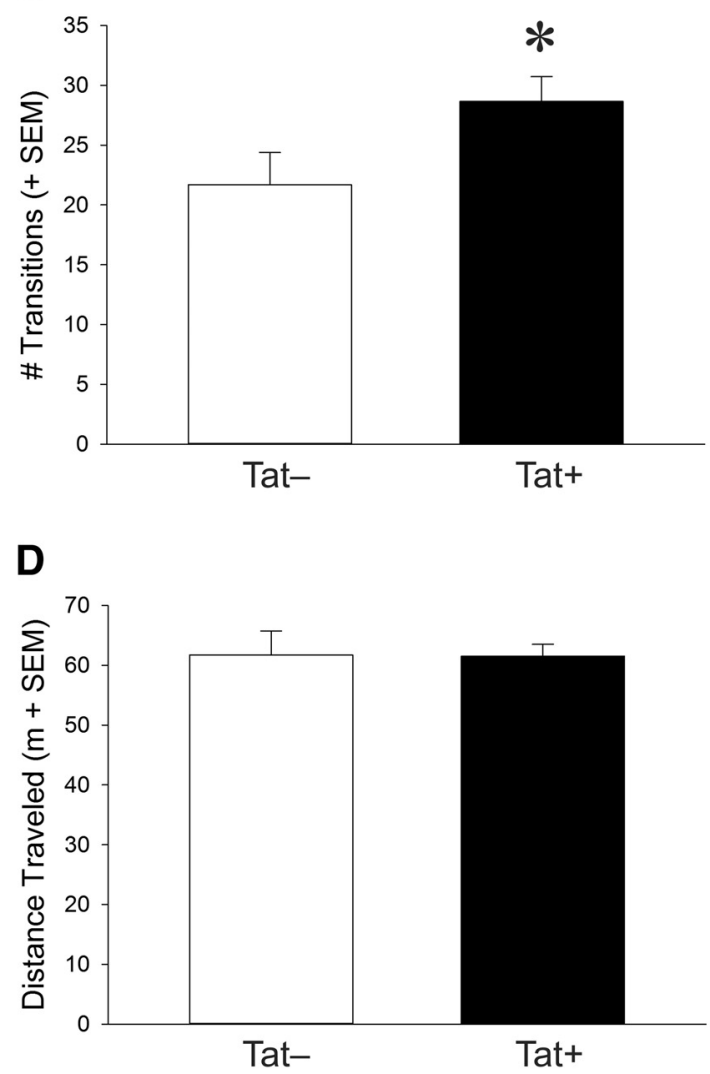

Figure 5. Anxiety-like and spontaneous motor behavior of equally represented Tat ${ }^{+}$and Tat ${ }^{-}$mice crossed to Drd1a-tdTomato or Drd2-eGFP reporter mice. Given that behavior did not differ significantly as a function of the D1 or D2 reporter, analyses of Tat genotype are shown. $\boldsymbol{A}-\boldsymbol{C}$, In a light- dark transition test, $\mathrm{Tat}^{+}$mice demonstrated significantly reduced latencies to exit the brightly lit chamber $(\boldsymbol{A})$, made more transitions between the light and dark chambers $(\boldsymbol{B})$, and demonstrated significantly greater rearing behavior $(\boldsymbol{C})$ than did Tat ${ }^{-}$control mice. $\boldsymbol{D}$, No differences were observed on spontaneous locomotor behavior in an open field as indicated by the total distance traveled. *Significant differences between Tat ${ }^{-}$and Tat ${ }^{+}$mice, $p<0.05$.

Table 2. HIV-1 Tat ${ }^{+}$and Tat ${ }^{-}$control transgenic mice were crossed to Drd1a-tdTomato or Drd2-eGFP reporter mice

\begin{tabular}{lcc}
\hline & Tat $^{-}$ & Tat $^{+}$ \\
\hline Light-dark transition & $(n=16)$ & $(n=17)$ \\
$\quad$ Time in light (s) & $242 \pm 24$ & $224 \pm 19$ \\
Open field & $(n=14)$ & $(n=18)$ \\
Velocity (cm/s) & $3.4 \pm 0.2$ & $3.4 \pm 0.1$ \\
Time mobile (s) & $1,071 \pm 42$ & $1,047 \pm 26$ \\
Time in center (s) & $167 \pm 32$ & $177 \pm 20$ \\
Rotarod (latency to fall; s) & $(n=9)$ & $(n=7)$ \\
Fixed-speed trial (10 rpm for 30 s) & $25 \pm 2$ & $25 \pm 2$ \\
Fixed-speed trial (10 rpm for 180 s) & $130 \pm 14$ & $127 \pm 12$ \\
Accelerated trial (0-20 rpm for 180 s) & $16.0 \pm 0.8$ & $16.6 \pm 0.4$ \\
Accelerated trial (0-40 rpm for 180 s) & $97 \pm 5$ & $94 \pm 6$ \\
\hline
\end{tabular}

Given that behavior did not differ significantly as a function of the D1 or D2 reporter, analyses of Tat genotype are shown. Mice were assessed for anxiety-like behavior in a light-dark transition task, for exploratory behavior in an open field, and for evoked locomotion on a rotarod. No significant differences were observed.

the go versus no-go circuitry of the basal ganglia (Crook and Housman, 2012; Ehrlich, 2012; Lee et al., 2016). Optogenetic studies indicate that high D2 MSN firing frequencies (comparable to our observations at $450 \mathrm{pA}$ ) are important for inhibiting downstream targets (Lee et al., 2016). The decreased input resistance in the D2 MSNs resulting in reduced firing rates at low current intensities and increased rheobase might cause circuit imbalances that favor a more hyperkinetic state; however, in HIV patients, hyperkinetic disorders are generally not observed without comorbid infections (Cardoso, 2002; Tse et al., 2004). Given the modest global neuropathology in our transgenic mouse model after 2 weeks of Tat induction and the absence of hypermotoric or hypomotoric movement deficits, the cumulative synaptodendritic damage might not yet be sufficient to unbalance the functionality of striatal motor circuits, but may nevertheless be sufficient to promote anxiety-like behaviors.

Our findings suggest that Tat expression restricts synaptic plasticity in D2 MSNs because the proportion of filopodia/thin dendritic spines decrease, whereas the percentage of stubby spines increase, implying diminished spine turnover (Fig. 3; Bhatt et al., 2009; Villalba and Smith, 2013). Although direct and indirect striatal projections from nucleus accumbens (NAc) MSNs do not segregate to the same degree as MSNs in the dorsal striatum (Smith et al., 2013), to the extent that our findings in dorsal striatum can be generalized to the NAc (Howard et al., 2009), reductions in D2 MSN plasticity may also disrupt behavioral processes involved in reward. Activation of D1 receptors is critical for psychostimulant self-administration (Xu et al., 2000; Caine et al., 2007; Karlsson et al., 2008), whereas stimulating D2 receptors blocks the behavioral effects of psychostimulants (Beyer and Steketee, 2002). D2 receptor-knock-out mice show increased psychostimulant sensitization (Sim et al., 2013). Notably, Tat exposure elevates dopamine content significantly in caudate putamen while reducing dopamine within the NAc (Kesby et al., 2016). This coincides with increased intracranial self-stimulation (Kesby et al., 2016), supporting prior demonstrations of Tatpotentiated conditioned place preference for cocaine or alcohol (Paris et al., 2014a, 2014b; McLaughlin et al., 2014). Tat may affect behavioral reward by reducing dopamine transporter ex- 
pression at the cell surface (Midde et al., 2012; Theodore et al., 2012) and/or through allosteric inhibition of the dopamine transporter (Zhu et al., 2011; Midde et al., 2013, 2015). Because D2 MSNs reportedly act by countering the development of place preference and sensitization to amphetamine or cocaine (Durieux et al., 2009; Ferguson et al., 2011; Heinsbroek et al., 2017), Tat-induced impairment of D2 MSN function may promote drug-seeking behavior. Evidence of increased cocaine selfadministration related to striatal dysfunction has been reported in an HIV-1 transgenic rat model (McIntosh et al., 2015).

Our work reveals that a subpopulation of striatal MSNs is selectively vulnerable to the effects of HIV-1 and suggests that HIV exposure may damage specific neurocircuits preferentially, resulting in a characteristic spatiotemporal pattern of CNS damage and behavioral deficits. The underlying circuit-level deficits will be uniquely modified in individual patients depending on genetic factors, sex differences, age at infection, and the cumulative effects of drug exposure or other unique environmental factors. Because damage to specific neural circuits will affect specific behaviors, it is predicted that the range of behaviors affected by Tat and other HIV proteins will broaden as additional extrastriatal and intrastriatal circuits become impaired during the disease course.

\section{References}

Ade KK, Wan Y, Chen M, Gloss B, Calakos N (2011) An improved BAC transgenic fluorescent reporter line for sensitive and specific identification of striatonigral medium spiny neurons. Front Syst Neurosci 5:32. CrossRef Medline

Agrawal L, Louboutin JP, Marusich E, Reyes BA, Van Bockstaele EJ, Strayer DS (2010) Dopaminergic neurotoxicity of HIV-1 gp120: reactive oxygen species as signaling intermediates. Brain Res 1306:116-130. CrossRef Medline

Aksenov MY, Aksenova MV, Nath A, Ray PD, Mactutus CF, Booze RM (2006) Cocaine-mediated enhancement of Tat toxicity in rat hippocampal cell cultures: the role of oxidative stress and D1 dopamine receptor. Neurotoxicology 27:217-228. CrossRef Medline

Aksenov MY, Aksenova MV, Mactutus CF, Booze RM (2012) D1/NMDA receptors and concurrent methamphetamine + HIV-1 Tat neurotoxicity. J Neuroimmune Pharmacol 7:599-608. CrossRef Medline

Augood SJ, Faull RL, Emson PC (1997) Dopamine D1 and D2 receptor gene expression in the striatum in Huntington's disease. Ann Neurol 42:215221. CrossRef Medline

Berger JR, Kumar M, Kumar A, Fernandez JB, Levin B (1994) Cerebrospinal fluid dopamine in HIV-1 infection. AIDS 8:67-71. CrossRef Medline

Bertran-Gonzalez J, Bosch C, Maroteaux M, Matamales M, Hervé D, Valjent E, Girault JA (2008) Opposing patterns of signaling activation in dopamine D1 and D2 receptor-expressing striatal neurons in response to cocaine and haloperidol. J Neurosci 28:5671-5685. CrossRef Medline

Beyer CE, Steketee JD (2002) Cocaine sensitization: modulation by dopamine D2 receptors. Cereb Cortex 12:526-535. CrossRef Medline

Bhatt DH, Zhang S, Gan WB (2009) Dendritic spine dynamics. Annu Rev Physiol 71:261-282. CrossRef Medline

Blomeley CP, Cains S, Bracci E (2015) Dual nitrergic/cholinergic control of short-term plasticity of corticostriatal inputs to striatal projection neurons. Front Cell Neurosci 9:453. CrossRef Medline

Brady AM, O’Donnell P (2004) Dopaminergic modulation of prefrontal cortical input to nucleus accumbens neurons in vivo. J Neurosci 24:10401049. CrossRef

Bruce-Keller AJ, Turchan-Cholewo J, Smart EJ, Geurin T, Chauhan A, Reid R, Xu R, Nath A, Knapp PE, Hauser KF (2008) Morphine causes rapid increases in glial activation and neuronal injury in the striatum of inducible HIV-1 Tat transgenic mice. Glia 56:1414-1427. CrossRef Medline

Caine SB, Thomsen M, Gabriel KI, Berkowitz JS, Gold LH, Koob GF, Tonegawa S, Zhang J, Xu M (2007) Lack of self-administration of cocaine in dopamine D1 receptor knock-out mice. J Neurosci 27:13140-13150. CrossRef Medline

Calabresi P, Picconi B, Tozzi A, Ghiglieri V, Di Filippo M (2014) Direct and indirect pathways of basal ganglia: a critical reappraisal. Nat Neurosci 17:1022-1030. CrossRef Medline

Cardoso F (2002) HIV-related movement disorders. CNS Drugs 16:663668. CrossRef Medline

Cepeda C, André VM, Yamazaki I, Wu N, Kleiman-Weiner M, Levine MS (2008) Differential electrophysiological properties of dopamine D1 and D2 receptor-containing striatal medium-sized spiny neurons. Eur J Neurosci 27:671-682. CrossRef Medline

Chandra T, Maier W, König HG, Hirzel K, Kögel D, Schüler T, Chandra A, Demirhan I, Laube B (2005) Molecular interactions of the type 1 human immunodeficiency virus transregulatory protein Tat with $N$-methyl-Daspartate receptor subunits. Neuroscience 134:145-153. CrossRef Medline

Chergui K, Lacey MG (1999) Modulation by dopamine D1-like receptors of synaptic transmission and NMDA receptors in rat nucleus accumbens is attenuated by the protein kinase $\mathrm{C}$ inhibitor Ro 32-0432. Neuropharmacology 38:223-231. CrossRef Medline

Chuhma N, Tanaka KF, Hen R, Rayport S (2011) Functional connectome of the striatal medium spiny neuron. J Neurosci 31:1183-1192. CrossRef Medline

Crawley J, Goodwin FK (1980) Preliminary report of a simple animal behavior model for the anxiolytic effects of benzodiazepines. Pharmacol Biochem Behav 13:167-170. Medline

Crook ZR, Housman DE (2012) Dysregulation of dopamine receptor D2 as a sensitive measure for Huntington disease pathology in model mice. Proc Natl Acad Sci U S A 109:7487-7492. CrossRef Medline

D’Aversa TG, Eugenin EA, Berman JW (2005) NeuroAIDS: contributions of the human immunodeficiency virus-1 proteins tat and gp120 as well as CD40 to microglial activation. J Neurosci Res 81:436-446. Medline

Day M, Wokosin D, Plotkin JL, Tian X, Surmeier DJ (2008) Differential excitability and modulation of striatal medium spiny neuron dendrites. J Neurosci 28:11603-11614. CrossRef Medline

Debaisieux S, Rayne F, Yezid H, Beaumelle B (2012) The ins and outs of HIV-1 Tat. Traffic 13:355-363. CrossRef Medline

DeVaughn S, Müller-Oehring EM, Markey B, Bronte-Stewart HM, Schulte T (2015) Aging with HIV-1 infection: motor functions, cognition, and attention - a comparison with Parkinson's disease. Neuropsychol Rev 25: 424-438. CrossRef Medline

di Rocco A, Bottiglieri T, Dorfman D, Werner P, Morrison C, Simpson D (2000) Decreased homovanilic acid in cerebrospinal fluid correlates with impaired neuropsychologic function in HIV-1-infected patients. Clin Neuropharmacol 23:190-194. CrossRef Medline

Durieux PF, Bearzatto B, Guiducci S, Buch T, Waisman A, Zoli M, Schiffmann SN, de Kerchove d'Exaerde A (2009) D $_{2}$ R striatopallidal neurons inhibit both locomotor and drug reward processes. Nat Neurosci 12 : 393-395. CrossRef Medline

Ellis R, Langford D, Masliah E (2007) HIV and antiretroviral therapy in the brain: neuronal injury and repair. Nat Rev Neurosci 8:33-44. CrossRef Medline

Ehrlich ME (2012) Huntington's disease and the striatal medium spiny neuron: cell-autonomous and non-cell-autonomous mechanisms of disease. Neurotherapeutics 9:270-284. CrossRef Medline

Eugenin EA, King JE, Nath A, Calderon TM, Zukin RS, Bennett MV, Berman JW (2007) HIV-tat induces formation of an LRP-PSD-95-NMDARnNOS complex that promotes apoptosis in neurons and astrocytes. Proc Natl Acad Sci U S A 104:3438-3443. CrossRef Medline

Ferguson SM, Eskenazi D, Ishikawa M, Wanat MJ, Phillips PE, Dong Y, Roth BL, Neumaier JF (2011) Transient neuronal inhibition reveals opposing roles of indirect and direct pathways in sensitization. Nat Neurosci 14:2224. CrossRef Medline

Fitting S, Xu R, Bull C, Buch SK, El-Hage N, Nath A, Knapp PE, Hauser KF (2010) Interactive comorbidity between opioid drug abuse and HIV-1 Tat: chronic exposure augments spine loss and sublethal dendritic pathology in striatal neurons. Am J Pathol 177:1397-1410. CrossRef Medline

Fitting S, Scoggins KL, Xu R, Dever SM, Knapp PE, Dewey WL, Hauser KF (2012) Morphine efficacy is altered in conditional HIV-1 Tat transgenic mice. Eur J Pharmacol 689:96-103. CrossRef Medline

Fitting S, Knapp PE, Zou S, Marks WD, Bowers MS, Akbarali HI, Hauser KF (2014a) Interactive HIV-1 Tat and morphine induced synaptodendritic injury is triggered through focal disruptions in $\mathrm{Na}^{+}$influx, mitochondrial instability, and $\mathrm{Ca}^{2+}$ overload. J Neurosci 34:12850-12864. CrossRef Medline

Fitting S, Zou S, El-Hage N, Suzuki M, Paris JJ, Schier CJ, Rodríguez JW, 
Rodriguez M, Knapp PE, Hauser KF (2014b) Opiate addiction therapies and HIV-1 Tat: interactive effects on glial $\left[\mathrm{Ca}^{2+}\right]_{i}$, oxyradical and neuroinflammatory chemokine production and correlative neurotoxicity. Curr HIV Res 12:424-434. Medline

Fitting S, Stevens DL, Khan FA, Scoggins KL, Enga RM, Beardsley PM, Knapp PE, Dewey WL, Hauser KF (2016) Morphine tolerance and physical dependence are altered in conditional HIV-1 Tat transgenic mice. J Pharmacol Exp Ther 356:96-105. CrossRef Medline

Fu X, Lawson MA, Kelley KW, Dantzer R (2011) HIV-1 Tat activates indoleamine 2,3 dioxygenase in murine organotypic hippocampal slice cultures in a p38 mitogen-activated protein kinase-dependent manner. J Neuroinflammation 8:88. CrossRef Medline

Gelman BB (2015) Neuropathology of HAND with suppressive antiretroviral therapy: Encephalitis and neurodegeneration reconsidered. Curr HIV/ AIDS Rep 12:272-279. CrossRef Medline

Gerfen CR, Wilson CJ (1996) The basal ganglia. In: Handbook of chemical neuroanatomy, Vol 12. Integrated systems of the CNS, Part III: Cerebellum, basal ganglia, olfactory system. Handbook of chemical neuroanatomy (Swanson LW, Björklund A, Hökfelt T eds), pp 371-468. New York: Elsevier.

Gerfen CR (1992) The neostriatal mosaic: multiple levels of compartmental organization in the basal ganglia. Annu Rev Neurosci 15:285-320. Medline

Gertler TS, Chan CS, Surmeier DJ (2008) Dichotomous anatomical properties of adult striatal medium spiny neurons. J Neurosci 28:1081410824. CrossRef Medline

Graybiel AM (2008) Habits, rituals, and the evaluative brain. Annu Rev Neurosci 31:359-387. CrossRef Medline

Hahn YK, Podhaizer EM, Farris SP, Miles MF, Hauser KF, Knapp PE (2015) Effects of chronic HIV-1 Tat exposure in the CNS: heightened vulnerability of males versus females to changes in cell numbers, synaptic integrity, and behavior. Brain Struct Funct 220:605-623. CrossRef Medline

Hahn YK, Paris JJ, Lichtman AH, Hauser KF, Sim-Selley LJ, Selley DE, Knapp PE (2016) Central HIV-1 Tat exposure elevates anxiety and fear conditioned responses of male mice concurrent with altered mu-opioid receptor-mediated G-protein activation and $\beta$-arrestin 2 activity in the forebrain. Neurobiol Dis 92:124-136. CrossRef Medline

Hall C, Ballachey EL (1932) A study of the rat's behavior in a field: a contribution to method in comparative psychology. University of California Publications in Psychology 6:1-12. Available from: http://psycnet.apa.org/psycinfo/1932-04321-001.

Harris KM, Jensen FE, Tsao B (1992) Three dimensional structure of dendritic spines and synapses in rat hippocampus (CA1) at postnatal day 15 and adult ages: implications for the maturation of synaptic physiology and long-term potentiation. J Neurosci 12:2685-2705. Medline

Haughey NJ, Holden CP, Nath A, Geiger JD (1999) Involvement of inositol 1,4,5-trisphosphate-regulated stores of intracellular calcium in calcium dysregulation and neuron cell death caused by HIV-1 protein tat. J Neurochem 73:1363-1374. Medline

Heinsbroek JA, Neuhofer DN, Griffin WC $3^{\text {rd }}$, Siegel GS, Bobadilla AC, Kupchik YM, Kalivas PW (2017) Loss of plasticity in the D2-accumbens pallidal pathway promotes cocaine seeking. J Neurosci 37:757-767. CrossRef Medline

Horn A, Scheller C, du Plessis S, Arendt G, Nolting T, Joska J, Sopper S, Maschke M, Obermann M, Husstedt IW, Hain J, Maponga T, Riederer P, Koutsilieri E; German Competence Network HIV/AIDS (2013) Increases in CSF dopamine in HIV patients are due to the dopamine transporter 10/10-repeat allele which is more frequent in HIV-infected individuals. J Neural Transm 120:1411-1419. CrossRef Medline

Howard EC, Schier CJ, Wetzel JS, Gonzales RA (2009) The dopamine response in the nucleus accumbens core-shell border differs from that in the core and shell during operant ethanol self-administration. Alcohol Clin Exp Res 33:1355-1365. CrossRef Medline

Hriso E, Kuhn T, Masdeu JC, Grundman M (1991) Extrapyramidal symptoms due to dopamine-blocking agents in patients with AIDS encephalopathy. Am J Psychiatry 148:1558-1561. CrossRef Medline

Hu XT (2016) HIV-1 Tat-mediated calcium dysregulation and neuronal dysfunction in vulnerable brain regions. Curr Drug Targets 17:4-14. Medline

Jakel RJ, Maragos WF (2000) Neuronal cell death in Huntington's disease: a potential role for dopamine. Trends Neurosci 23:239-245. CrossRef Medline

Karlsson RM, Hefner KR, Sibley DR, Holmes A (2008) Comparison of do- pamine D1 and D5 receptor knockout mice for cocaine locomotor sensitization. Psychopharmacology (Berlin) 200:117-127. CrossRef Medline

Kaul M, Garden GA, Lipton SA (2001) Pathways to neuronal injury and apoptosis in HIV-associated dementia. Nature 410:988-994. CrossRef Medline

Kemp JM, Powell TP (1971) The structure of the caudate nucleus of the cat: light and electron microscopy. Philos Trans R Soc Lond B Biol Sci 262: 383-401. CrossRef Medline

Kesby JP, Markou A, Semenova S (2016) The effects of HIV-1 regulatory TAT protein expression on brain reward function, response to psychostimulants and delay-dependent memory in mice. Neuropharmacology 109:205-215. CrossRef Medline

Kieburtz KD, Epstein LG, Gelbard HA, Greenamyre JT (1991) Excitotoxicity and dopaminergic dysfunction in the acquired immunodeficiency syndrome dementia complex: therapeutic implications. Arch Neurol 48: 1281-1284. CrossRef Medline

Koutsilieri E, Riederer P, du Plessis S, Scheller C (2014) A short review on the relation between the dopamine transporter 10/10-repeat allele and ADHD: implications for HIV infection. Atten Defic Hyperact Disord 6:203-209. CrossRef Medline

Langford D, Masliah E (2001) Crosstalk between components of the blood brain barrier and cells of the CNS in microglial activation in AIDS. Brain Pathol 11:306-312. Medline

Larsson M, Hagberg L, Forsman A, Norkrans G (1991) Cerebrospinal fluid catecholamine metabolites in HIV-infected patients. J Neurosci Res 28: 406-409. CrossRef Medline

Lawson MA, Kelley KW, Dantzer R (2011) Intracerebroventricular administration of HIV-1 Tat induces brain cytokine and indoleamine 2,3dioxygenase expression: a possible mechanism for AIDS comorbid depression. Brain Behav Immun 25:1569-1575. CrossRef Medline

Lee HJ, Weitz AJ, Bernal-Casas D, Duffy BA, Choy M, Kravitz AV, Kreitzer AC, Lee JH (2016) Activation of direct and indirect pathway medium spiny neurons drives distinct brain-wide responses. Neuron 91:412-424. CrossRef Medline

Ma YY, Cepeda C, Chatta P, Franklin L, Evans CJ, Levine MS (2012) Regional and cell-type-specific effects of DAMGO on striatal D1 and D2 dopamine receptor-expressing medium-sized spiny neurons. ASN Neuro 4: pii: e00077. CrossRef Medline

Marks WD, Paris JJ, Schier CJ, Denton MD, Fitting S, McQuiston AR, Knapp PE, Hauser KF (2016) HIV-1 Tat causes cognitive deficits and selective loss of parvalbumin, somatostatin, and neuronal nitric oxide synthase expressing hippocampal CA1 interneuron subpopulations. J Neurovirol 22:747-762. CrossRef Medline

Masliah E, Heaton RK, Marcotte TD, Ellis RJ, Wiley CA, Mallory M, Achim CL, McCutchan JA, Nelson JA, Atkinson JH, Grant I (1997) Dendritic injury is a pathological substrate for human immunodeficiency virusrelated cognitive disorders. HNRC Group. The HIV Neurobehavioral Recearch Center. Ann Neurol 42:963-972. CrossRef Medline

Matamales M, Bertran-Gonzalez J, Salomon L, Degos B, Deniau JM, Valjent E, Hervé D, Girault JA (2009) Striatal medium-sized spiny neurons: identification by nuclear staining and study of neuronal subpopulations in BAC transgenic mice. PLoS One 4:e4770. CrossRef Medline

McArthur JC (2004) HIV dementia: an evolving disease. J Neuroimmunol 157:3-10. Medline

McIntosh S, Sexton T, Pattison LP, Childers SR, Hemby SE (2015) Increased sensitivity to cocaine self-administration in HIV-1 transgenic rats is associated with changes in striatal dopamine transporter binding. J Neuroimmune Pharmacol 10:493-505. CrossRef Medline

McLaughlin JP, Ganno ML, Eans SO, Mizrachi E, Paris JJ (2014) HIV-1 Tat protein exposure potentiates ethanol reward and reinstates extinguished ethanol-conditioned place preference. Curr HIV Res 12:415-423. Medline

Mesco ER, Joseph JA, Roth GS (1992) Selective susceptibility of cultured striatal neurons to kainic acid. J Neurosci Res 31:341-345. CrossRef Medline

Midde NM, Gomez AM, Zhu J (2012) HIV-1 Tat protein decreases dopamine transporter cell surface expression and vesicular monoamine transporter-2 function in rat striatal synaptosomes. J Neuroimmune Pharmacol 7:629-639. CrossRef Medline

Midde NM, Huang X, Gomez AM, Booze RM, Zhan CG, Zhu J (2013) Mutation of tyrosine 470 of human dopamine transporter is critical for HIV-1 Tat-induced inhibition of dopamine transport and transporter 
conformational transitions. J Neuroimmune Pharmacol 8:975-987. CrossRef Medline

Midde NM, Yuan Y, Quizon PM, Sun WL, Huang X, Zhan CG, Zhu J (2015) Mutations at tyrosine 88, lysine 92 and tyrosine 470 of human dopamine transporter result in an attenuation of HIV-1 Tat-induced inhibition of dopamine transport. J Neuroimmune Pharmacol 10:122-135. CrossRef Medline

Mirsattari SM, Power C, Nath A (1998) Parkinsonism with HIV infection. Mov Disord 13:684-689. CrossRef Medline

Nath A (2015) Eradication of human immunodeficiency virus from brain reservoirs. J Neurovirol 21:227-234. CrossRef Medline

Nath A, Anderson C, Jones M, Maragos W, Booze R, Mactutus C, Bell J, Hauser KF, Mattson M (2000) Neurotoxicity and dysfunction of dopaminergic systems associated with AIDS dementia. J Psychopharmacol 14:222-227. CrossRef Medline

Obermann M, Küper M, Kastrup O, Yaldizli O, Esser S, Thiermann J, Koutsilieri E, Arendt G, Diener HC, Maschke M; German Competence Network HIV/AIDS (2009) Substantia nigra hyperechogenicity and CSF dopamine depletion in HIV. J Neurol 256:948-953. CrossRef Medline

Ochs SM, Dorostkar MM, Aramuni G, Schön C, Filser S, Pöschl J, Kremer A, Van Leuven F, Ovsepian SV, Herms J (2015) Loss of neuronal GSK3 $\beta$ reduces dendritic spine stability and attenuates excitatory synaptic transmission via $\beta$-catenin. Mol Psychiatry 20:482-489. CrossRef Medline

Paris JJ, Eans SO, Mizrachi E, Reilley KJ, Ganno ML, McLaughlin JP (2013) Central administration of angiotensin IV rapidly enhances novel object recognition among mice. Neuropharmacology 70:247-253. CrossRef Medline

Paris JJ, Fenwick J, McLaughlin JP (2014a) Estrous cycle and HIV-1 Tat protein influence cocaine-conditioned place preference and induced locomotion of female mice. Curr HIV Res 12:388-396. Medline

Paris JJ, Singh HD, Ganno ML, Jackson P, McLaughlin JP (2014b) Anxietylike behavior of mice produced by conditional central expression of the HIV-1 regulatory protein, Tat. Psychopharmacology (Berl) 231:23492360. CrossRef Medline

Paris JJ, Zou S, Hahn YK, Knapp PE, Hauser KF (2016) $5 \alpha$-reduced progestogens ameliorate mood-related behavioral pathology, neurotoxicity, and microgliosis associated with exposure to HIV-1 Tat. Brain Behav Immun 55:202-214. CrossRef Medline

Perreault ML, Hasbi A, Alijaniaram M, Fan T, Varghese G, Fletcher PJ, Seeman P, O'Dowd BF, George SR (2010) The dopamine D1-D2 receptor heteromer localizes in dynorphin/enkephalin neurons: increased high affinity state following amphetamine and in schizophrenia. J Biol Chem 285:36625-36634. CrossRef Medline

Perreault ML, Hasbi A, O'Dowd BF, George SR (2011) The dopamine $\mathrm{d} 1-\mathrm{d} 2$ receptor heteromer in striatal medium spiny neurons: evidence for a third distinct neuronal pathway in basal ganglia. Front Neuroanat 5:31. CrossRef Medline

Potter MC, Figuera-Losada M, Rojas C, Slusher BS (2013) Targeting the glutamatergic system for the treatment of HIV-associated neurocognitive disorders. J Neuroimmune Pharmacol 8:594-607. CrossRef Medline

Repunte-Canonigo V, Lefebvre C, George O, Kawamura T, Morales M, Koob GF, Califano A, Masliah E, Sanna PP (2014) Gene expression changes consistent with neuroAIDS and impaired working memory in HIV-1 transgenic rats. Mol Neurodegener 9:26. CrossRef Medline

Sanna PP, Repunte-Canonigo V, Masliah E, Lefebvre C (2016) Pathway dysregulations associated with neuroAIDS in humans without HIVE. Soc Neurosci Abstr 770.01.

Saylor D, Dickens AM, Sacktor N, Haughey N, Slusher B, Pletnikov M, Mankowski JL, Brown A, VolskyDJ, McArthur JC (2016) HIV-associated neurocognitive disorder: pathogenesis and prospects for treatment. Nat Rev Neurol 12:234-248. CrossRef Medline

Scheller C, Arendt G, Nolting T, Antke C, Sopper S, Maschke M, Obermann M, Angerer A, Husstedt IW, Meisner F, Neuen-Jacob E, Müller HW, Carey P, Ter Meulen V, Riederer P, Koutsilieri E (2010) Increased dopaminergic neurotransmission in therapy-naïve asymptomatic HIV patients is not associated with adaptive changes at the dopaminergic synapses. J Neural Tramsm (Vienna) 117:699-705. CrossRef Medline

Silvers JM, Aksenova MV, Aksenov MY, Mactutus CF, Booze RM (2007) Neurotoxicity of HIV-1 Tat protein: involvement of D1 dopamine receptor. Neurotoxicology 28:1184-1190. CrossRef Medline

Sim HR, Choi TY, Lee HJ, Kang EY, Yoon S, Han PL, Choi SY, Baik JH (2013) Role of dopamine D2 receptors in plasticity of stress-induced addictive behaviours. Nat Commun 4:1579. CrossRef Medline

Smith RJ, Lobo MK, Spencer S, Kalivas PW (2013) Cocaine-induced adaptations in D1 and D2 accumbens projection neurons (a dichotomy not necessarily synonymous with direct and indirect pathways). Curr Opin Neurobiol 23:546-552. CrossRef Medline

Theodore S, Cass WA, Dwoskin LP, Maragos WF (2012) HIV-1 protein Tat inhibits vesicular monoamine transporter-2 activity in rat striatum. Synapse 66:755-757. CrossRef Medline

Tse W, Cersosimo MG, Gracies JM, Morgello S, Olanow CW, Koller W (2004) Movement disorders and AIDS: a review. Parkinsonism Relat Disord 10:323-334. CrossRef Medline

Tseng KY, O’Donnell P (2004) Post-pubertal emergence of prefrontal cortical up states induced by D1-NMDA co-activation. Cereb Cortex 15:4957. CrossRef Medline

Villalba RM, Smith Y (2013) Differential striatal spine pathology in Parkinson's disease and cocaine addiction: a key role of dopamine? Neuroscience 251:2-20. CrossRef Medline

Wilson CJ, Groves PM (1980) Fine structure and synaptic connections of the common spiny neuron of the rat neostriatum: a study employing intracellular inject of horseradish peroxidase. J Comp Neurol 194:599615. CrossRef Medline

Xu M, Guo Y, Vorhees CV, Zhang J (2000) Behavioral responses to cocaine and amphetamine administration in mice lacking the dopamine D1 receptor. Brain Res 852:198-207. CrossRef Medline

Zauli G, Secchiero P, Rodella L, Gibellini D, Mirandola P, Mazzoni M, Milani D, Dowd DR, Capitani S, Vitale M (2000) HIV-1 Tat-mediated inhibition of the tyrosine hydroxylase gene expression in dopaminergic neuronal cells. J Biol Chem 275:4159-4165. CrossRef Medline

Zhou L, Saksena NK (2013) HIV associated neurocognitive disorders. Infect Dis Rep 5:e8. CrossRef Medline

Zhu J, Mactutus CF, Wallace DR, Booze RM (2009) HIV-1 Tat proteininduced rapid and reversible decrease in $\left[{ }^{3} \mathrm{H}\right]$ dopamine uptake: dissociation of $\left[{ }^{3} \mathrm{H}\right]$ dopamine uptake and $\left[{ }^{3} \mathrm{H}\right] 2 \beta$-carbomethoxy-3- $\beta$-(4-fluorophenyl) tropane (WIN 35,428) binding in rat striatal synaptosomes. J Pharmacol Exp Ther 329:1071-1083. CrossRef Medline

Zhu J, Ananthan S, Mactutus CF, Booze RM (2011) Recombinant human immunodeficiency virus-1 transactivator of transcription ${ }_{1-86}$ allosterically modulates dopamine transporter activity. Synapse 65:1251-1254. CrossRef Medline 